\title{
ПОНЯТТЯ ТА ЗМІСТ КОНСТИТУЦІЙНОГО ПРАВА НА ЖИТЛО
}

Чайковський О. I.

Конституційне право на житло належить до фундаментальних прав та свобод людини і громадянина. Метою сучасного розвитку українського суспільства є утвердження прав людини і громадянина, забезпечення умов для їх повної реалізації. Це означає, що більшість прав і свобод, які ми маємо за Конституцією, як загальновизнані у світі стандарти можливої поведінки належать кожній людині від народження, а суспільство і держава це визнають як факт. Житло - це одна з основних матеріальних умов життя кожної людини. Потреба людини в житлі виникає з моменту їі народження, зберігається протягом усього життя $і$ припиняється лише після смерті. Таким чином, одним з самих важливих соціальних завдань держави $\epsilon$ задоволення потреби людини в житлі. Конституція України покладає на державу обов'язок створювати умови, за яких кожен громадянин матиме змогу побудувати житло, придбати його у власність або взяти в оренду. Тобто одним із показників добробуту громадян певної країни є забезпеченість їх житлом. Отже, в першу чергу слід визначитися 3 поняттям та змістом конституційного права на житло. Конституційні права і свободи людини i громадянина мають ряд властивостей і рис, які не тільки виділяють їх із загальної системи прав, а й зумовлюють їх вирішальну роль у визначенні правового статусу особи в суспільстві і державі. Оскільки права та свободи кожної людини, в тому числі й право на житло, набувають статусу конституційних лише після закріплення їх Конституцією України, то вони відрізняються від інших прав за змістом та формою закріплення. Це означає, що права і свободи людини і громадянина наділені верховенством, оскільки всі інші права і свободи повинні відповідати їм, а також вони є правовою базою для прийняття всіх інших прав і свобод, що деталізують їх. Отже, для реалізації права на житло перш за все необхідно здійснити науковопрактичний аналіз правової природи та змісту права громадян на житло.

Ключові слова: житло, нерухомість, нерухоме майно, будівлі, споруди, садівничі будівлі.

(с) Чайковський О. І., 2020
Chaikovskyi 0 . I. The notion and content of the constitutional right to housing

The constitutional right to housing is one of the fundamental human and citizen rights and freedoms. The goal of today's development of the Ukrainian society is to assert human and citizen rights and create conditions for the complete realization of these rights. It means that the majority of rights and freedoms, guaranteed to us by the Constitution as the standards of possible behavior generally accepted worldwide, belong to every person from the birth, and the society and the government recognize that as a fact. Housing is one of the most important material conditions for life of every person. A person needs housing from the very moment of their birth, continues to need it during their entire life, and no longer needs it only after the death. Therefore, one of the government's most important social tasks is to meet the person's need in housing. The Constitution of Ukraine obliges the government to create conditions in which every citizen is able to build, purchase or lease a house. In other words, one of the indicators of the population's wellbeing in a particular country is the availability of housing. Therefore, the notion and content of the constitutional right to housing must be defined first of all. The constitutionally-guaranteed human and citizen rights and freedoms have a number of properties and features that not only highlight them in the general system of rights but also define their decisive role in determining the person's legal status in the society and the country. Since the rights and freedoms of every person, including the right to housing, become constitutional only after being embedded in the Constitution of Ukraine, they differ from other rights in terms of content and embedment form. It means that human and citizen rights and freedoms have the supremacy, because all other rights and freedoms must be conformant with them, and also, they serve as the legal basis for the adoption of all other rights and freedoms that provide details of these fundamental rights. Therefore, in order to realize the right to housing a scientific-practical analysis of the legal nature and content of the citizen right to housing must be done, first of all.

Key words: housing, real estate, immovable property, buildings, structures, garden buildings.

Постановка проблеми та їі актуальність. Забезпеченість кожної людини та громадянина житлом - це необхідна умова нормальної 
життєдіяльності кожної людини. Тому саме пріорітетним завданням нашої держави $€$ можливість людини і громадянина мати житло і користуватися ним та вимагати від зобов'язаних суб'єктів забезпечення реалізації цього права у повному обсязі. Проте для реалізації цього права необхідно визначитись з його поняттям та змістом. В умовах сьогодення право на отримання житла виступає рушійним механізмом соціально-економічного розвитку суспільства та держави та однією з найбільш гострих проблем в Україні, а тому актуальність обраної теми та методи ії дослідження $\epsilon$ виправданими.

Аналіз останніх досліджень і публікацій. У межах правового регулювання права на житло як комплексного правового утворення наукові дослідження поняття та змісту такого права проводилися в працях багатьох авторів, оскільки ця тема не $\epsilon$ новою, зокрема, Ю.В. Кириченко, М.В. Долгополова, Л.О. Мойсей, М.К. Галянтич, О.Є. Аврамова, Л.Г. Лічман та інших. Проте сьогодні це питання все ж слід визначити як малодосліджене, а тому потребує більш детального дослідження для реалізації права на житло в сучасних умовах.

Метою цієї статті $\epsilon$ визначення поняття та змісту права на житло з метою належного захисту цього конституційного права та дослідження правового змісту права на житло з метою вирішення проблем, які виникають у процесі реалізації цього права.

Виклад основного матеріалу. Самостійною проблемою виступає визначення змісту права на житло як в загально-теоретичному, так і в конституційно-правовому аспекті, адже єдності думок науковців щодо цього питання сьогодні не спостерігається.

Як зазначає В.В. Калюжний, право особи на житло $€$ невіддільним природним правом людини, життя якої немислиме без житла. Це пов'язано з потребою людини у відмежуванні від природи та соціуму, що визначають як сферу приватності особи. Одночасно вчений вказує, що права особи на житло не отримали належного механізму реалізації, будучи частково розпиленими між окремими актами цивільного й конституційного законодавства, тоді як дослідження щодо поняття і змісту права на житло, елементів житлової правоздатності особи, способів реалізації житлових прав, форм і способів захисту житлових прав та інтересів особи існують здебільшого на рівні теорії [8, с. 62].

Точним вбачається зауваження, що право на житло «діє не відокремлено, а в тісній взаємодії з іншими конституційними правами, насамперед із правом на свободу вибору місця проживання, правом на соціальний захист, правом на недоторканність житла та $\epsilon$ складовою частиною права на достатній життєвий рівень для себе і своєї сім'ї» $[9$, c. 33].

Однак сьогодні слід погодитись із думкою, що Конституція України, визнавши право людини на житло одним з основних прав і свобод людини та громадянина, фактично не розкриває повністю його змісту, що слугує підставою для різних тлумачень і неоднозначних висновків з приводу його змісту та встановлення обов'язку забезпечення осіб житлом з боку держави [8, с. 63] Наведене ще більшою мірою обґрунтовує необхідність ретельного дослідження змісту права на житло як обов'язковий етап його правового захисту.

Право на житло, з точки зору Є.О. Харитонова, М.К. Галянтича Л.Г. Лічмана та інших дослідників, може зводитись до трьох юридичних можливостей:

- стабільного стійкого, постійного користування займаним жилим приміщенням;

- можливості поліпшення житлових умов;

- забезпечення здорового середовища проживання, житлового середовища, гідного цивілізованої людини, що закріплюється Загальною декларацією з прав людини [7, с. 37]

Так, окрема група правовмочностей (юридично гарантованих можливостей) суб'єкта права на житло та благ, які таким правом гарантуються, певною мірою охороняється ч. 3 ст. 1 Закону України «Про забезпечення санітарного та епідемічного благополуччя населення», який визначає середовище життєдіяльності людини - сукупність об'єктів, явищ і факторів навколишнього середовища (природного і штучно створеного), що безпосередньо оточують людину і визначають умови ii проживання, харчування, праці, відпочинку, навчання, виховання тощо». Також відповідно ч. 5 ст. 38 Закону встановлюється переважне право на одержання житла з відповідними умовами для певних категорій медичних працівників.

Російська дослідниця М.І. Стєрхова під правом на житло розуміє юридично врегульовану можливість кожної людини в Росії бути постійно забезпеченою житлом на умовах, що відповідають ii соціальному статусу. Наведений підхід дещо деталізує розуміння права на житло. При цьому дещо неоднозначним вбачається зв'язок із поняттям «соціальний статус особи». Необхідною стає наявність чіткого юридичного визначення даної категорії та можливості присвоєння конкретній 
особі відповідного соціального статусу. Інакше не гарантується рівність умов забезпечення права на житло [20, с. 7].

У світлі зазначеного слід зафіксувати тезу, що конституційне право на житло має гарантувати загальнодоступний, рівний для кожного мінімум «достатнього житла», що відповідав би техніко-побутовим, санітарним та іншим стандартам, які задовольняють фізіологічні та соціально-економічні потреби людини на умовах, що відповідають іï правам. При цьому справедливо, що ступінь сприяння реалізації цього права має випливати з особливостей стану здоров'я, рівня забезпеченості та інших характеристик становища конкретної особи. Сукупність цих особливостей визначає об'єм та характер обов'язків держави щодо такого сприяння.

Своєю чергою питання відповідності житла більш високим вимогам та показникам комфортності, площі чи технологізації $є$ приватною справою особи та їі індивідуальною прерогативою. Ці питання лише частково $\epsilon$ «клопотом» держави, яка зобов'язана насамперед дбати про забезпечення достатнім житлом кожного громадянина (передусім малозахищених категорій осіб) до того рівня, якого вимагає конституція та міжнародні правові стандарти, а також сприяти покращенню житлових умов. Підвищення такого рівня над мінімальними показниками лише частково складає предмет суб'єктивного конституційного права на житло. Водночас у формі мінімально гарантованої сукупності можливостей особи щодо житлових умов право на житло $є$ постійним правом громадянина, що виникає з його народженням а припиняється у зв'язку зі смертю або через скасування відповідного закону [7, с. 38]. При цьому теза щодо скасування закону як підстави для припинення права людини на житло залишається відкритим питанням та тяжіє до спростування.

Наведене вище підтверджує позиція O.В. Коваль, на думку якої право на житло - це право фізичної особи мати нерухомість, яка відповідає встановленим законодавством ознакам житла та відносно якої особа може здійснювати в тій чи іншій формі право власності [11]. Втім, даним підходом деталізовано здебільшого матеріальний аспект розглядуваного права.

В основі розуміння права на житло лежить його ідентифікація як невіддільної частини прав людини, чим обґрунтована важливість захисту цього права. Природний характер права на житло зумовлює необхідність закріплення даного права для кожної особи на конституційному рівні та в міжнародно-правових актах [3, с. 157]. В цьому підході розкрито універсальність права на житло, а головне його «статус», що має значення для обґрунтування, зокрема, обов'язку держави щодо захисту та забезпечення права на житло.

Неоднорідність галузевої природи права на житло також зазначається багатьма вченими. Л.О. Мойсей доцільно вказує, що право громадянина на житло має як цивільно-правовий, так i адміністративний характер, а захист прав на житло досягається адміністративними, цивільними, кримінальними та процесуальними засобами. При цьому категорія «житло» пов'язується з конституційним, житловим, цивільним, адміністративним, господарськими галузями права, хоча у зв'язку із наявною специфікою не поглинається цими сферами [19, с. 120-121].

3 правом на житло пов'язують також низку юридичних інтересів, зокрема, інтереси щодо: реалізації природного права на житло; стабільного користування займаним жилим приміщенням; покращення житлових умов; захисту житлових інтересів від незаконного вилучення житла; недопустимості обмеження житлових прав та інтересів [2]. Віднесення вказаних правовомочностей суб'єкта права на житло до юридичних інтересів $\epsilon$ питанням дискусійним, однак у будь-якому разі не виключає необхідності їх правового захисту.

Водночас згідно з рішенням Конституційного Суду України від 1 грудня 2004 р. № 18/рп/2004: «Поняття «охоронюваний законом інтерес», що вживається в частині першій статті 4 Цивільного процесуального кодексу України та інших законах України у логічно-смисловому зв'язку 3 поняттям «права», треба розуміти як прагнення до користування конкретним матеріальним та/або нематеріальним благом, як зумовлений загальним змістом об'єктивного і прямо не опосередкований у суб'єктивному праві простий легітимний дозвіл, що є самостійним об'єктом судового захисту та інших засобів правової охорони з метою задоволення індивідуальних і колективних потреб, які не суперечать Конституції і законам України, суспільним інтересам, справедливості, добросовісності, розумності та іншим загальноправовим засадам». Так, стосовно права на житло наведене визначення дещо розширює поле дії не лише самого права, але й об'єм охоронюваних правом благ, що підлягають одночасно і правовому захисту.

Юридична практика сучасних держав поєднує концепцію природно-правового характеру права на житло та позитивістський підхід до їх 
формального закріплення. [18, с. 68-70] Вказаний шлях видається найбільш прогресивним та коректним.

Детально зазначену концепцію розкриває Л.О. Мойсей, справедливо зауважуючи, що право на житло недоцільно тлумачити у вузькому або обмеженому розумінні, оскільки це ототожнювало 6 дане право з наданням притулку, «даху над головою» чи наданням оселі як предмету вжитку, тоді як вказаним правом забезпечується можливість гідного, мирного та безпечного проживання будь-де на власний розсуд [17, с. 86]. Дану тезу обґрунтовує й інший підхід. Зокрема, предметно ілюструє юридичну природу права на житло людини та ціннісно-правову природу «житла» наукова позиція, яку займає Г.Г. Мойсей. Дослідником зазначено, що справи про соціальні права $\epsilon$ такими, що пов'язані з правом на людську гідність, бо людина не може бути об'єктом державної політики, якщо вона не має ні одягу, ні житла [16, с. 63].

Особливо це положення набуває чітко визначеної цінності в контексті розуміння людської гідності як фундаментального, складного явища, що включає як внутрішню впевненість людини у власній цінності та почуття самоповаги як джерела спротиву будь-яким намаганням посягнути на свою індивідуальність і незалежність, так і в якості об'єктивної сукупності особистих прав, свобод, реалізація яких дозволяє кожній людині стати, бути і залишатися особистістю [5, с. 10-11].

о.Є. Аврамова розглядає право на житло у вузькому та широкому розумінні. У вузькому розумінні зміст права на житло, на думку вченої, полягає у можливості отримати житло (на ринку житла або з фонду соціального призначення, зокрема при його позбавленні) та користуватися ним (суб'єктивне право на житло). У широкому розумінні право на житло передбачає низку правомочностей особи, а саме: володіння, користування та розпорядження житлом; створення механізмів і умов, за яких кожний громадянин мав би змогу побудувати житло, придбати його у власність або отримати у користування; використання та розпорядження приватним житлом на власний розсуд, з дотриманням закону; створення умов для забезпечення житлом малозабезпечених верств населення і людей без визначеного місця проживання, введення державного контролю за умовами проживання людини для надання адресної допомоги; створення умов охорони житла; невтручання у сферу приватного життя, що здійснюється у житлі; неможливість позбавлення житла, крім випадків, передбачених законом [1, с. 5]. Дана теза та наведена класифікація допомагають розкрити юридичну природу права на житло, хоча наводяться в загально-теоретичному аспекті.

Зміст права на житло різні дослідники розуміють неоднаково, що $\epsilon$ принциповим для розкриття теми захисту даного права. На думку Ю.В. Кириченко, сутність права на житло вижарена в можливості побудувати житло, придбати його у власність, взяти в оренду чи одержати від держави чи органу місцевого самоврядування безоплатно. Вчений вважає, що зміст права на житло складають житлові умови, житлові блага, їх одержання, поліпшення чи зміна, задоволення житлових потреб [10, с. 304]. Ця позиція доцільно враховує сукупність охоронюваним законом благ, які гарантовані особі у зв'язку із її правом на житло.

На думку М.К. Галянтича, елементами права на житло виступають: визначення категорій громадян, які потребують поліпшення житлових умов, право на одержання житла будь-яким способом; захист цього права від будь-яких протиправних посягань всіма доступними засобами [3, с. 160]. Такий підхід розкриває лише окремий аспект права на житло, хоча вченим охоплено деякі з раніше не вказаних його складників. Окрім того, науковець відносить захист права на житло до змісту цього права, розкриваючи їх тісну органічну пов'язаність.

Л.Г. Лічман визначає зміст права на житло як гарантовану законом можливість збудувати чи придбати житло у власність, отримати в користування житло, що $є$ об'єктом права власності, або винаймати об'єкт власності, набути право користування житлом у якості членів сім'ї власника житлового приміщення, а також у якості осіб, які постійно проживають із наймачем житла, а також стабільно користуватися житлом в умовах свободи вибору місця проживання і цивілізованого (безпечного) середовища існування, яке забезпечується державними гарантіями недоторканності житла і недопущення свавільного його позбавлення [14, с. 101]. Цей підхід $\epsilon$ доволі змістовним, оскільки вченим враховано найсуттєвіші конституційно-правові ознаки права на житло, що характеризують і зміст цього права. Окрім того, перелічені гарантії та вимоги щодо недоторканності житла та заборони свавільного його позбавлення дійсно можна визнати органічним складником змісту права на житло насамперед у зв'язку з тим, що сама категорія житла, гарантована кожному його конституційним правом, передбачає відповідну стандартизацію, визнаючи в даній якості лише придатне, достатнє та безпечне житло. 
Що ж до недоторканості житла, на думку В.В. Кожана, це право слід віднести до такої категорії прав, які випливають з права на життя. Науковцем зазначено, що саме такі права складають систему юридичних гарантій (юридичних засобів і способів охорони й захисту прав і свобод людини та громадянина як окремого індивіда) [12, с. 126]. Цей аспект ширше розкриває А.Р. Туманянс, зазначаючи, що право на недоторканність житла чи іншого володіння - це перш за все не охорона житла, а захист і повага людини, що проживає в ньому, а також їі приватного життя, що зумовлює розгляд вказаного права як невіддільного елементу забезпечення права на недоторканість приватного життя людини [21, с. 78-80].

Своєю чергою елементами змісту недоторканності житла як складника права на житло вважають здійснення людиною особистого життя у своєму житлі на свій розсуд; встановлення відповідного регламенту поведінки у житлі як інших фізичних і юридичних осіб, так і держави; учинення перешкод незаконному вторгненню; можливість захищатися від спроб незаконного позбавлення житла, зокрема від незаконного переселення та від умисного руйнування; можливість захищатися від агресивних дій і дій, що турбують: від надмірного шуму, інших порушень, зокрема ущільненої забудови; здійснення комплексу дій по охороні житла від негативного впливу оточуючого середовища; надання наймачеві житла права на захист від його власника [1, с. 6].

Ю.В. Кириченко та В.М. Долгополова зазначають, що право на житло в Україні отримало порівняно розширене закріплення. На думку вчених, змістом права на житло $є$ житлові умови, житлові блага, їх одержання, поліпшення чи зміна, задоволення житлових потреб [9, с. 33]. Н.С. Марценко вказує, що, гарантуючи кожній людині право на житло, держава зобов'язується створювати умови, за яких реалізація цієї гарантії матиме місце в реальних правовідносинах [15]. Наведеним підходом висвітлено участь держави в реалізації права особи на житло. Ця участь втілюється у вжитті державою комплексу економікоправових організаційних та інших заходів реалізації особою права на житло. Зазначена діяльність держави здійснюється в межах їі обов'язку, що кореспондує праву громадянина на житло.

При цьому важливим $є$ розуміння форм реалізації житла, що мають бути забезпечені. На думку Є.О. Харитонова, І.В. Давидової та О.М. Берназ-Лукавецької, основними формами реалізації конституційного права на житло є: 1) будівництво житла; 2) придбання житла у власність; 3) оренда житла; 4) безкоштовне отримання житла [6, с. 12].

Важливою $\epsilon$ позиція С.С. Коновальчикової. Вченою запропоновано виокремлювати в змісті конституційного права на житло абсолютні правомочності, які не можуть бути обмежені за жодних обставин (право мати житло, право на державний захист у разі свавільного позбавлення житла, право вимагати створення умов для реалізації права на житло), а також правомочності, що можуть бути обмеженні за дотримання конституційних умов (правомочності відносно конкретного житла як майнового об'єкту, правомочність отримання державної допомоги [13, с. 9].

Справедливим видається також зауваження, що зміст конституційного права на житло розкривається в переліку правомочностей, що включені в це право, однак лише таких, якими визначено його конституційно правову сутність. В такому підході некоректним вважається включення до місту вказаного права тих правомочностей, що регулюються іншими галузями права, або складають самостійне конституційне право (право на недоторканість житла) [4, с. 8].

Висновки. Саме право на житло є складним правом та комплексним, яке охоплює конституційно-правові та цивільно-правові аспекти. Поняття права на житло, яке є одним з основних прав і свобод людини, як суб'єктивного права людини і громадянина, з одного боку, надає громадянам можливість мати безпечне, гідне, вільне від вторгнення житло, з іншого - зобов'язує державу вживати всіх належних заходів щодо надання жила як у власність, так і в користування.

\section{Література}

1. Аврамова О.Є. Позбавлення суб'єктивного права на житло : автореф. дис... канд. юрид. наук : 12.00.03. Харків. 2008. 27 с.

2. Галянтич М.К. Поняття житлових інтересів фізичної особи. Приватне право і підприємництво. 2016. Вип. 15. С. 14-18.

3. Галянтич М.К., Тилик Т.М. Поняття житлових прав. Приватне право $і$ підприємництво. 2018. Вип. 18. С. 155-159.

4. Герасимов Р. А. Конституционное право на жилище и механизм его реализации : автореф. дис. ... канд. юрид. наук. 12.00.02. Москва, 2005. 21 с.

5. Головко О.М. Гідність людини як моральна основа ії прав. Національні та міжнародні механізми захисту прав людини : тези доп. всеукр. круглого столу (м. Харків, 20 квіт. 2016 р.), Харків., 2016. С. 10-11. 
6. Житлове право : навч.-метод. посіб. / за ред : $€$ Є.О. Харитонова, О.М. Берназ-Лукавецької. Одеса : Фенікс, 2019. 120 с.

7. Житлове право України : навч. посіб. / за ред Є.О. Харитонова. Київ: Істина, 2008. 159с.

8. Калюжний В.В. Право на житло та цивільноправовий захист житлових прав: цивільно-правовий аналіз. Вісник Запорізького національного університету. Юридичні науки. 2016. № 1. С. 60-69.

9. Кириченко Ю.В., Долгополова М.В. Застосування європейського досвіду щодо конституційноправового регулювання права на житло. Юридичний науковий електронний журнал. 2018. № 3. С. 30-35.

10. Кириченко Ю.В. Конституційно-правове регулювання прав людини в Україні в контексті гармонізації з законодавством європейських держав: дис. ... д-ра юрид. наук: 12.00.02 / Держ. ВНЗ «Ужгород. нац. ун-т» М-ва освіти і науки України. Ужгород, 2018. $424 \mathrm{c}$.

11. Коваль О.В. Первісні та похідні способи виникнення права власності на житло. URL: http:// elar.naiau.kiev.ua/bitstream/123456789/13381/ $1 /$ Проб.\%20та\%20стан\%20дотр.\%20захист._р 187-189.pdf.

12. Кожан В.В. Особисті права людини: загальнотеоретична характеристика : автореф. дис. ... канд. юрид. наук : 12.00.01 / Національний університет «Львівська політехніка». Львів, 2016. 210 с.

13. Коновальчикова С.С. Конституционное право на жилище и пределы его реализации при развитии застроенной территории : автореф. дис. ... канд. юрид. наук. 12.00.02. Омск, 2019. 20с.

14. Лічман Л.Г. Поняття та зміст права на житло. Університетські наукові записки. 2005. № 4 (16). С. 99-103

15. Марценко Н.С. Встановлення меж здійснення житлових прав шляхом їх законодавчих обмежень
Теорія і практика правознавства. 2014. Вип. 2. URL: http://nbuv.gov.ua/UJRN/tipp_2014_2_12.

16. Мойсей Г.Г. Гідність людини як об'єкт судового захисту. Сучасні виклики та актуальні проблеми судової реформи в Україні: матеріали III міжнар. наук.-практ. конф., м. Чернівці, 24-25 жовт. 2019 р. Чернівці, 2019. С. 62-64.

17. Мойсей Л.О. Джерела права на достатнє житло в межах міжнародних норм у галузі прав людини. Вісник Київського національного університету імені Тараса Шевченка. Юридичні науки. 2014. Вип. 1. С. 86-90.

18. Мойсей Л.0. Доктринальні дослідження конституційного права людини на житло. Юридичний вісник. Повітряне і космічне право. 2014. № 1. С. 68-70.

19. Мойсей Л.О. Житло як основа стабільності суспільства. Наукові записки Львівського університету бізнесу та права. 2010. Вип. 4. С. 117-124.

20. Стерхова М.И. Особенности реализации конституционного права кавдого на жилище в Российской федерации через ипотечное жилищное кредитование: автореф. дис. ... канд. юрид. наук. 12.00.02. Москва. 2005. 21с.

21. Туманянц А.Р. Міжнародно-правовий досвід забезпечення засади недоторканності житла чи іншого володіння особи. Актуальні проблеми удосконалення кримінального процесуального законодавства: матеріали всеукр. наук.-практ. конфер., м. Одеса, 21 квіт. 2017 р. Одеса, 2017. С. 78-80.

Чайковський О. I., старший викладач кафедри філософії, політології, психології і права одеської державної академії будівництва та архітектури 